\title{
Problems of training qualified personnel for agriculture
}

\author{
Gusel R. Fassakhova ${ }^{1}$, Rosa V. Gataullina ${ }^{1}$, Lilya R. Islamova ${ }^{1}$, Lyubov G. Chumarova ${ }^{2 *}$, and Rezida I. Mukhametzyanova ${ }^{2}$ \\ ${ }^{1}$ Kazan State Agrarian University, 420015 Kazan, Russia \\ ${ }^{2}$ Kazan (Volga Region) Federal University, 420008 Kazan, Russia
}

\begin{abstract}
The authors of the article researched the problem of training high-qualified experts to agricultural business. It is analyzed the difficulties of training students at agricultural university of Tatarstan Republic. Tatarstan Republic takes the leader position in growing agricultural products in Russian Federation. It is very important to train modern experts for agricultural business who can use up-to-date technics to grow organic corns, who can work with advanced technologies not damaging environment. The authors researched the questionaries' of the school graduates to find the answer to the question as to why young graduates do not want to work in agriculture; why it is very difficult to attract school graduate to agrarian university; what difficulties agrarian university graduates have in agricultural business. The conclusions of this article are based on some surveys done by the authors of this research. The authors found out that there are many reasons for decreasing the number of students to agricultural business as lack of social infrastructure, low income and hard work in rural areas what reduce the motivation of young people to work in agriculture. Understanding all these disadvantages, the faculty of Kazan State Agrarian University tries to improve the situation by modernizing educational process towards individualization of educational system.
\end{abstract}

\section{Introduction}

The aim of the article is to study the situation with the training future experts for agricultural business in the territory of Tatarstan. Firstly, Tatarstan is in the third place in production of food in Russian Federation where the agriculture needs more and more highly qualified and educated specialists. The area of farmland of the Republic of Tatarstan is 4.5 million hectares, of which arable land is 3.4 million hectares. Having $2.3 \%$ of the agricultural land area of the Russian Federation, RT produces about $6 \%$ of its agricultural products, $12.7 \%$ of the gross regional product, including agriculture $-7.5 \%$. Rural population of the republic comprises about 900 thousand people, including those of working age - about 500 thousand people.

The number of employees in the agro-industrial complex of the republic is 112.9 thousand people, of which: 79.1 thousand people are in agricultural production, and about 34 thousand people are in service organizations and processing enterprises.

Employment in the economy of the republic: $11 \%$ of the working population, incl. - 7\% in agriculture [1]. Agriculture in Tatarstan is a highly developed sector of the economy. However, there are some problems in this sector of the economy. First of all, in training experts for agricultural business. The authors work at agrarian university and know the situation as it is.

\section{Materials and methods}

The objectives of our investigation are: 1) to define the difficulties in training personnel for agriculture; 2) to determine the current situation in the fields of agricultural business; 3 ) to study the local and international experience of training experts for agriculture to enhance the effectiveness of training personnel. For confirmation of the hypothesis we need to turn to a variety of methods:

- the method of historical and logical analysis of regulatory documents of home and foreign governments and research papers of leading scientists connected with training personnel for agriculture;

- study and theoretical analysis and synthesis of social, political and pedagogical literature;

- analysis, comparison, synthesis and generalization of innovative foreign and domestic experience in training personnel for agriculture;

- comparison of data of domestic research on this issue.

The works of foreign and Russian researchers in the field of training personnel for agriculture (G. Silaste, Mc Granahan, D.Konstantinovsky, M. Butyaykin, A.Valeev, D. Faizrakhmanov etc. ) were the theoretical basis of our study [2-5].

The usage of the methodology and methods of existing research contributes to the development of scientific thought in training personal for agriculture. It provides the opportunity to comprehensively address the problem of training highly qualified experts for agricultural business.

\footnotetext{
Corresponding author: chumarova@yandex.ru
} 


\section{Results}

According to experts of the Institute of Agrarian Problems of the Russian Academy of Sciences, agriculture is one of the most important fields of business because the health of the nation depends on healthy food. But at the same time it is a subject to numerous, often difficult to foresee risks. One of the worst consequences of "food risks" is the death of people from starvation, inadequate (poor quality) nutrition and crops grown with chemical fertilizers, which increase cancer disease of people.

Among the 10 main sources of individual strategic risks of unnatural loss of human lives, factors of food poisoning and starvation are 164-177 thousand people per year, which equals $9-11 \%$ of the total number of untimely dead people in Russia.

Today all fields of agricultural business are more complicated and more technologically developed than they were just 50 years ago. Agriculture needs highly qualified, experienced workers who can use modern technologies in this field. But we have some problems. On the one hand, agricultural universities should prepare highly qualified experts, but on the other hand, these welleducated specialists do not want to work in agriculture. In other words, we have the problem of "brain drain" from the villages to the cities. That means agricultural universities prepare more and more experts but graduates do not go to work into the agricultural sector of the economy.

Some young experts reeducate themselves and try to find their jobs in the cities, in other fields of industries but not in agriculture. A year to a year less and less graduates go to work into agricultural business. Nevertheless, the growing population demands more food and agriculture needs more qualified workers. Moreover, population needs healthy organic food, crops which are grown with compliance of all technological processes as transporting, storage and processing food.

According to the researcher G. G. Silaste, excessive orientation of social policy in the field of education to urban youth, together with a high level of poverty in villages and the very low prestige of rural labor, is one of the strongest factors contributing to the departure of young people from villages to cities after high school [4].

How can agricultural universities solve these problems? A number of researchers believe that it is impossible to cope with the problem of "brain drain" from the villages to the cities. They believe that the investments in the development of rural education ultimately leads to the fact that those cities where the most motivated, educated and trained young people aspire to become beneficiaries [6].

However, our experience shows that direct investments to the agrarian field do not help to develop it without highly qualified personnel who are able to use modern technologies. The existing gap between the education and the economy, between education and science, lack of mutual integration of science, higher education and agricultural business hinder the process of effective and timely updating of the content of educational programs. The outdated material and technical base of agricultural universities as well as high cost of its modernization do not allow them to create a modern base of innovative educational technologies at their own expense. Under these conditions, the lag in the level of training of specialists from the pace of development of production becomes a big problem.

Thus, in the agricultural sector of the country's economy, at the present stage, a contradictory situation is developing with the provision of personnel. On the one hand, rural unemployment is aggravating, and there is an acute shortage of jobs. On the other hand, there is an acute lack of skilled workers and specialists who can manage advanced high-tech projects with a progressive style of thinking and doing business.

In this situation, the best way of teaching qualified personnel for agriculture is signing an agreement between big industrial companies and agrarian universities. Big companies can help to modernize the technical base of an agrarian university. As for the university, it can bring organic products which grow on the experimental fields to the workers of big companies.

Currently, the Russian Federation and the Republic of Tatarstan actively take part in national projects in the field of agricultural development and education. Large investors have appeared in the agricultural sector of the economy of Tatarstan in recent years. They successfully use advanced resource-saving technologies for cultivating crops with modern high-performance equipment, based on the latest technologies and highly productive cattle. These investors sponsor not only developing of livestock production, but also building of modern livestock complexes and updating the equipment and technical base. In the nearest future, this will develop the republic's agriculture on an industrial basis [5].

Today, agriculture is already becoming a high-tech sector of the national economy. The investors are interested in modern scientific researches in the field of agriculture, and they give financial support to scientific researches.

Other serious reasons to hope that the agricultural field will have professional training agricultural specialists in the nearest future in the Republic of Tatarstan are:

- $\quad$ the realization of the priority national projects "Education", "Development of the agricultural industrial complex", and "Health", in which it is very important to ensure food security of the country by expanding the production of environmentally friendly and competitive agricultural products;

- Russia's entry into the Bologna process that actualizes the transition to a multilevel education system and the need to develop an intra-university quality system, implement international standards for assessing and monitoring of academic performance, and develop professional mobility;

- modernization of agriculture and forestry, a fundamental change in the legal and regulatory framework for agricultural activity and production.

Kazan State Agricultural university tries to open its departments in other districts, not only in Kazan. It is very important for training agricultural personnel for many reasons. Firstly, it makes education affordable for students who live far from Kazan. Students can study 
close to their living places, training at the place of residence. This way, students can save significant financial costs (traveling to the place of study, living in a hostel, etc.). Secondly, students can combine work with study, getting theoretical knowledge and practical skills.

Some authors emphasize a clearly manifested tendency: the claims on the level of life typical of rural graduates are lower compared with urban graduates of schools [7]. Based on the results of a study conducted by the Institute of Sociology of the Russian Academy of Sciences in 2006, in terms of the availability of quality education, rural youth remains one of the most socially disadvantaged groups. According to them, the existing social inequality in access to full-fledged education among rural youth predetermines the further insufficiency of their human capital.

According to the data of some Russian authors, for students in rural schools, the dominant attitude is the desire to get a well-paid job in the cities. An interesting fact is that after receiving a higher education, people from more prosperous rural families are more likely to return to villages than people from poorer families (in $40 \%$ of cases versus $10 \%$ of cases, respectively). Thus, the level of material well-being of rural families is a very significant factor hindering migration from villages [8].

Every year the personnel problem becomes more acute, both in specialists and in working professions (annual reduction in recent years - 6-9\%). Currently, in the Russian Federation, the Republic of Tatarstan, there is an active implementation of national projects in the field of the development of the agro-industrial complex and education.

At the same time, in recent years, large investors have come to the agrarian sector of the economy of Tatarstan. They quite successfully introduce advanced resourcesaving technologies of cultivation of agricultural crops using modern high-performance equipment, develop animal husbandry efficiently on the basis of the newest technologies and highly productive livestock, build powerful animal-breeding complexes, update the material and technical base. In the nearest future, all these efforts will help to develop the agriculture of the republic on an industrial basis.

Graduates who work in these up to date agro-industrial complexes get well-paid jobs, some benefits from the companies, they can improve their skills, and they understand that agriculture is becoming a high-tech sector of the national economy. Russian agrarian universities try to train qualified workers and specialists who are able to manage advanced high-tech projects that have a progressive style of thinking and running a business [9].

Defending the need for new approaches in the agroindustrial complex system, many experts and scientists speak about the absence of: a state training program in the agro-industrial complex system at the republic level; cooperation and coordination of actions of ministries, departments of educational institutions of all levels; effective integration of vocational education and vocational training; social partnership with business; separation from innovation processes in the republic, which create a serious obstacle to the reproduction of human potential in the industry.
All these factors lead to the situation where the share of graduates with higher agricultural education who return to their places of residence does not exceed $30-40 \%$ in Russia as a whole [10].

\section{Discussion}

What should be done to improve the situation? The answer is in improving the system of training future specialists for agriculture. We have some good results. Firstly, today, the agricultural scientific and educational complex of the Republic of Tatarstan is a combination of organizations in the field of science and education of various status, forms of ownership and departmental affiliation.

The core of the agrarian scientific and educational complex consists of: three research institutes - the Tatar Scientific Research Institute of Agriculture of the Russian Academy of Agricultural Sciences (RAAS); the Tatar Research Institute of Agrochemistry and Soil Science of the RAAS; the Sate Scientific Institute (SSI) "Federal Center of Toxicological and Radiation Safety"; two institutions of higher professional education - Kazan State Agrarian University, Federal State Educational Institution of Higher Professional Education, Kazan State Academy of Veterinary Medicine; one institution of additional professional education - FGOU DPO "Tatar Institute for Retraining of Agribusiness Personnel".

Kazan State Agrarian University (KSAU) takes the leading place in the structure of the agricultural research and educational complex. It is one of the dynamically developing universities of the Republic of Tatarstan, providing training of highly qualified agro engineering personnel in the fields of agriculture and forestry. The university has good experience in the field of research and educational activities, with a unique scientific, technical and personnel potential, there are opportunities for training, retraining and advanced training of personnel in many areas of agricultural production.

In March 2007, in accordance with the decision of the Government of the Republic of Tatarstan, Kazan State Agrarian University signed 14 Agreements with the Ministry of Agriculture and Food of the Republic of Tatarstan, the Ministry of Education and Science of the Republic of Tatarstan, large agricultural producers and the Heads of the municipalities of the Republic of Tatarstan. The aim of this is the integration of education, science and industry, providing the necessary material and technical base and the introduction of advanced high technologies in agricultural production.

All these efforts help attract graduates from the secondary schools to study at agrarian university. The students have a chance to work during studying years and make their grounded decisions. The students can also change the departments at the university if they realize that they have made wrong decision in the first course. The university does a lot to develop distant learning for the students who run their business in agriculture and cannot study full-time.

What kind of measures does the university faculty do to improve the situation in training personnel for 
agriculture? First of all, we work with high-school students. There are annual meetings at schools for round table discussion to clarify the advantages of agricultural jobs. The faculty organizes some meetings with parents several times a year. At these meetings, professors inform parents and their children about university programs and departments, discuss the interests of students and their parents, as well as social and emotional needs, subjects, which are important at agrarian universities: mathematics, biology, chemistry, physics, botany etc.

One of the most effective ways of high school students" "capture" for studying at agrarian university is inviting them to the "open door" days. These are special days at the university when prospective students can come for the meeting with faculty and ask some important questions about their future study and work, about educational programs, scholarship, possibilities to study abroad etc. These "open days" help students of the secondary schools to achieve self-determination with their future jobs.

Moreover, students can visit special machine and tractor fleet where they study modern high technological Russian and foreign equipment and machines operating in agriculture of Russian Federation.

They also have a chance to watch the experience of the faculty in the fields, listen to some reports about researching of the professors. Kazan State Agrarian University opens new departments for the students as landscape designers, as well as seed selection departments.

The university also try to give a chance for getting a double degree when university graduates can find jobs in different fields of agriculture, e.g. agronomist and seed grower or landscape designer and an economist etc.

\section{Conclusion}

Lack of social infrastructure, low wages and lack of prestige of work in rural areas reduce the motivation of young people to work in agriculture. Some difficulties influence the decrease of qualified workers in agriculture. These are high dependence of work in agriculture on climatic conditions, significant financial costs (travel to the place of study, living in a dormitory, etc.) which lead to an outflow of young people and qualified personnel to the cities.

There is a lack of scientific and regulatory support for training personnel and specialists for the agro industrial complex. There is also no annual monitoring to identify the need for specific specialists.

There are no prognostic and advanced models for changing the cluster of specialties for the agro industrial complex.

All this prevents the adequate reproduction of qualified personnel for the agro-industrial complex. The decrease in the share of rural residents against the background of the general population growth of the planet leads to an increasing consumption of food and increases the technological burden on the environment.

Understanding all these disadvantages, the faculty of Kazan State Agrarian University tries to improve the situation by modernizing educational process and changing the old methods of work, as well as working towards individualization of educational system.

\section{Acknowledgements}

The work is performed according to the Russian Government Program of Competitive Growth of Kazan State Agrarian University.

\section{References}

1. A. Valiev, G. Fassakhova, L. Shagivaliev, F. Nezhmetdinova, B. Ziganshin, Employment of graduates of agricultural universities: problems, successful experience and practical solutions (Kazan State Agrarian university, 2018)

2. D. Faizrakhmanov, A.R. Valiev, F.T. Nezhmetdinova, G.D. Krupina, Agricultural scientific and educational potential of the Republic of Tatarstan and the directions of its development Bulletin of Kazan State Agrarian University 3(9), 510 (2008)

3. D. Konstantinovsky, Self-determination or adaptation? The World of Russia 2, 123-143

4. G. Silaste, The influence of media on the life plans of rural young people Sociological Studies 12, 95-102 (2008)

5. M. Butyaykin, Modern employment issues for graduates of agrarian and economic universities Retrieved from: http://sisupr.mrsu.ru/20114/PDF/11/Nacharkina.pdf

6. Mc. Granahan, D. A. Ghelfi, The education crisis and rural stagnation in the 1980s in Education and rural economic development: Strategies for the 1990s (United States Department of Agriculture, Washington, DC, 1991)

7. V. Magun, M. Engovatov, Life claims of various social groups of young people in V. B. Zvonovsky, Youth of the Samara region in 2002: current situation and development trends 194-223 (Samara, 2003)

8. R. Kazakbaev, Assumptions of youth of Bashkortostan to life in the village Sociological studies 11, 77-81 (2005)

9. T. Abankina, A. Krasilova, G. Yastrebov, Education as a start for life: the life plans of rural schoolchildren in Russia Education Issues 2, 87-89 (2008)

10. P. Mikheev, Dynamics of life values of rural youth Sociological studies 1, 91-94 (2005) 